\title{
Papież a Promulgacja zbioróW POWSZechnego PRAWA KANONICZNEGO
}

\section{Wstęp}

Lex non obligat nisi promulgata ${ }^{1}$.

Promulgacja to termin pochodzący od łacińskiego czasownika promulgo, -are, oznaczającego: ogłosić publicznie, podać do publicznej wiadomości (zapowiedzieć) projekt ustawy, opublikować, zapowiedzieć ${ }^{2}$ Publiczne ogłoszenie ustawy stanowi istotny element procesu legislacyjnego, zarówno w systemie prawa świeckiego, jak i prawa kanonicznego ${ }^{3}$. Gracjan w procesie powstawania i obowiązywania ustawy wymienił sekwencję czterech zdarzeń, mianowicie: ustanowienie ustawy (leges instituuntur), promulgację (promulgantur), obowiązywanie (wejście w życie) (firmantur) oraz uznanie jej poprzez zgodne z nią postępowanie (cum moribus utentium

* Ks. dr hab., prof. KUL, Katedra Historii, Norm Ogólnych, Prawa Sakramentów i Instytutów Życia Konsekrowanego,Wydział Prawa, Prawa Kanonicznego i Administracji, Katolicki Uniwersytet Lubelski Jana Pawła II, e-mail: kburczak@kul.pl, https:/ / orcid.org/ 0000-0002-9829-6852.

1 D. Liebs, Lateinische Rechtsregeln und Rechtssprichwörter, C.H. Beck, wyd. 6, München 1998, L-37, s. 123; K. Burczak, A. Dębiński, M. Jońca, Eacińskie sentencje i powiedzenia prawnicze, C.H. Beck, wyd. 3, Warszawa 2018, L-46, s. 139. Ta reguła stała się również przedmiotem analiz św. Tomasza z Akwinu, Summa Theologica 2, 90, 4: „Ad quartum sic proceditur. Videtur quod promulgatio non sit de ratione legis. Lex enim naturalis maxime habet rationem legis. Sed lex naturalis non indiget promulgatione. Ergo non est de ratione legis quod promulgetur".

2 Promulgo, w: Stownik łacińsko-polski, t. 4, red. M. Plezia, Warszawa 1998, s. 336; Promulgo, w: J. Sondel, Stownik łacińsko-polski dla prawników i historyków, Kraków 1997, s. 796.

3 W Konstytucji RP art. 88 ust. 1: „Warunkiem wejścia w życie ustaw, rozporządzeń oraz aktów prawa miejscowego jest ich ogłoszenie". Kodeks Prawa Kanonicznego 1983 kan. 7: „Ustawa powstaje z chwilą jej promulgowania”. 
approbantur $)^{4}$. Św. Tomasz twierdził, że wydaje się (videtur $)^{5}$, iż promulgacja nie należy do uzasadnienia ustawy. Powołuje się na prawo naturalne (lex naturalis), które posiada najgłębsze uzasadnienie, a nie potrzebuje promulgacji. Wyciąga stąd wniosek, że nie należy do uzasadnienia ustawy to, że jest promulgowana ${ }^{6}$. Do jej właściwości należy to, że zobowiązuje do czynienia bądź nie czynienia czegoś. Do zachowania ustawy są zobowiązani nie tylko ci, przed którymi jest promulgowana, lecz także inni. Wyciąga

4 d. p. c. 3, D. 4.

5 Tomasz z Akwinu, Suma Teologiczna, t. 13: Prawo (1-2.90-105), przetłumaczył, w objaśnienia i skorowidze zaopatrzył o. Pius Bełch O.P, Londyn [b.r.w.], 2, 90, 4, s. 8: „Zdaje się, że do istoty prawa nie należy jego publiczne obwieszczenie (promulgatio), bo: 1. Prawo naturalne ma w sobie jak najbardziej istotne cechy prawa, a jednak nie potrzebuje publicznego obwieszczenia. A więc nie należy ono do istoty prawa. 2. Do prawa należy właściwie zobowiązywać do czynienia lub nie czynienia czegoś. Lecz do zachowania prawa zobowiązani są nie tylko ci, wobec których publicznie obwieszczono prawo lecz także inni. A więc obwieszczenie to nie należy do istoty prawa. 3. Obowiązek zachowania prawa rozciąga się i na przyszłość. Mówi bowiem Kodeks Justyniana: «Prawa swoją siłą obowiązującą obejmują sprawy, które zajdą w przyszłości» Lecz publicznego obwieszczenia dokonuje się wobec obecnych teraz osób. A więc nie należy ono koniecznie do istoty prawa. Wbrew temu w Dekretach Gracjana czytamy: «Prawa nabierają mocy z chwilą ich publicznego obwieszczenia». Odpowiedź: Jak się rzekło, prawo nadaje się innym w charakterze normy (prawidła) i miernika (ich postępowania). Prawidło zaś i miernik nadaje się przez to, że się przykłada do tego, co ma być normowane i mierzone. Stąd też, żeby prawo miało moc wiążącą - a to przecież jest istotną właściwością prawa - musi ono dotrzeć do tych ludzi, którzy powinni według niego normować swoje postępowanie. A dotrzeć może jedynie przez to, że dochodzi ono do ich wiadomości przez jego publiczne obwieszczenie. I dlatego publiczne obwieszczenie jest konieczne do tego, żeby prawo nabrało swojej mocy. Z tych czterech artykułów można ułożyć określenie prawa, mianowicie jest to rozporządzenie (ordinatio) rozumu dla dobra wspólnego nadane i publicznie obwieszczone przez tego, kto ma pieczę nad wspólnotą. Na 1. Publiczne obwieszczenie prawa natury dokonuje się już przez to samo, że sam Bóg wszczepił je w umysły ludzi tak, że jest ono poznawane w sposób naturalny. Na 2. Ci, wobec których prawo nie zostało (bezpośrednio) obwieszczone, są zobowiązani do jego zachowania, jako, że po jego publicznym obwieszczeniu dochodzi ono lub może dojść do ich wiadomości poprzez innych. Na 3. Publiczne obwieszczenie prawa dokonane w teraźniejszości rozciąga się i na przyszłość, a to dzięki utrwaleniu go na piśmie, które poniekąd na zawsze obwieszcza je publicznie. Toteż Izydor powiada: «Prawo-lex wywodzi swoją nazwę od legere-czytać, jako, że jest spisane»".

6 Tomasz z Akwinu, Summa Theologica 2, 90, 4: "Videtur quod promulgatio non sit de ratione legis. Lex enim naturalis maxime habet rationem legis. Sed lex naturalis non indiget promulgatione. Ergo non est de ratione legis quod promulgetur". 
wniosek, że promulgacja nie wynika z uzasadnienia ustawy ${ }^{7}$. Znajomość teorii prawa pozwoliła mu na konstatację, że obowiązywanie ustaw dotyczy przyszłości, ponieważ regulują one zdarzenia przyszłe, a promulgacja dokonuje się wobec obecnych, a więc promulgacja nie jest konieczna z ustawy (nie wynika z samej ustawy; nie wpływa na moc wiążącą ustawy). Sam przyznał, że ten tok jego analizy jest przeciwny do tego, co twierdzi Gracjan. W Dekrecie Gracjana, w dictum, twierdzi on, że „ustawy są ustanawiane, gdy są promulgowane ${ }^{\prime \prime}$. W odpowiedzi na tę trudność Tomasz stwierdził, że należy powiedzieć, iż ustawa jest nakładana na innych

7 Tomasz z Akwinu, Summa Theologica 2, 90, 4: „Praeterea, ad legem pertinet proprie obligare ad aliquid faciendum vel non faciendum. Sed non solum obligantur ad implendam legem illi coram quibus promulgatur lex, sed etiam alii. Ergo promulgatio non est de ratione legis".

8 Ze względu na to, że zagadnienie to nie jest wiodącym przedmiotem niniejszego opracowania, zostają wskazane tylko sposoby argumentacji Tomasza.

[37451] I Ia-IIae q. 90 a. 4 arg. 2 Praeterea, ad legem pertinet proprie obligare ad aliquid faciendum vel non faciendum. Sed non solum obligantur ad implendam legem illi coram quibus promulgatur lex, sed etiam alii. Ergo promulgatio non est de ratione legis.

[37452] I'-IIae q. 90 a. 4 arg. 3 Praeterea, obligatio legis extenditur etiam in futurum, quia leges futuris negotiis necessitatem imponunt, ut iura dicunt. Sed promulgatio fit ad praesentes. Ergo promulgatio non est de necessitate legis.

[37453] I I-IIae q. 90 a. 4 s. c. Sed contra est quod dicitur in decretis, IV dist., quod leges instituuntur cum promulgantur.

[37454] I I'-IIae q. 90 a. 4 co. Respondeo dicendum quod, sicut dictum est, lex imponitur aliis per modum regulae et mensurae. Regula autem et mensura imponitur per hoc quod applicatur his quae regulantur et mensurantur. Unde ad hoc quod lex virtutem obligandi obtineat, quod est proprium legis, oportet quod applicetur hominibus qui secundum eam regulari debent. Talis autem applicatio fit per hoc quod in notitiam eorum deducitur ex ipsa promulgatione. Unde promulgatio necessaria est ad hoc quod lex habeat suam virtutem. Et sic ex quatuor praedictis potest colligi definitio legis, quae nihil est aliud quam quaedam rationis ordinatio ad bonum commune, ab eo qui curam communitatis habet, promulgata. [37455] I'-Ilae q. 90 a. 4 ad 1 Ad primum ergo dicendum quod promulgatio legis naturae est ex hoc ipso quod Deus eam mentibus hominum inseruit naturaliter cognoscendam.

[37456] I' ${ }^{\text {-IIae }}$ q. 90 a. 4 ad 2 Ad secundum dicendum quod illi coram quibus lex non promulgatur, obligantur ad legem servandam, inquantum in eorum notitiam devenit per alios, vel devenire potest, promulgatione facta.

[37457] I Ia-IIae q. 90 a. 4 ad 3 Ad tertium dicendum quod promulgatio praesens in futurum extenditur per firmitatem Scripturae, quae quodammodo semper eam promulgat. Unde Isidorus dicit, in II Etymol., quod lex a legendo vocata est, quia scripta est.

9 d. p. c. 3, D. 4 Leges instituuntur, cum promulgantur, firmantur, cum moribus utentium approbantur. 
na sposób zasady i przepisu (miary). Zasada zaś i przepis są nakładane przez to, że odnoszą się do tych rzeczy, które porządkuje się i wyznacza się im miarę. Stąd odnośnie do tego, że ustawa zawiera [w sobie] moc wiązania, co jest jej właściwością, trzeba, żeby była udzielona (dana) ludziom, którzy według niej powinni być porządkowani. Takie udzielenie dokonuje się przez to, że dochodzi do ich wiadomości z samej promulgacji. Stąd promulgacja konieczna jest do tego, żeby ustawa miała swoją moc. I w ten sposób, opierając się na tych czterech wcześniej wskazanych elementach, może zostać sformułowana definicja ustawy, która jest niczym innym, jak pewnym zarządzeniem rozumu dla dobra wspólnego promulgowanym przez tego, kto ma troskę o wspólnotę. Odnośnie więc do pierwszego należy powiedzieć, że promulgacja prawa naturalnego jest z tego samego, że Bóg wszczepił je w umysły ludzi i należy je rozpoznać w naturalny sposób. Odnośnie do drugiego należy stwierdzić, że ci, wobec których nie jest promulgowana ustawa, są zobowiązani do jej zachowania, o ile doszła do ich wiadomości przez innych albo może dojść po dokonaniu promulgacji. Odnośnie do trzeciego należy powiedzieć, że obecna promulgacja rozciąga się na przyszłość przez trwałość Pisma, które w pewien sposób zawsze ją promulguje. Stąd Izydor w ks. II Etymologii mówi, że „ustawa jest nazywana od czytania, ponieważ została napisana [tłum. - K.B.]"10.

\section{Compilatio III (chronologicznie druga)}

Najwyższy ustawodawca kościelny stanowił od początku Kościoła prawo, ale nie gromadził swoich ustaw w zbiory. Czynili to prywatni autorzy. Kanony soborowe były podpisywane przez papieża lub jego legatów i w ten sposób stawały się obowiązującym prawem. Papież nie wydawał odrębnego dokumentu, poprzez który dokonywałby promulgacji swoich ustaw. Taka sytuacja miała miejsce aż do 1210 r. Było to związane ze zbiorem nazywanym Compilatio III. Był to jeden z pięciu zbiorów, które zostały zaakceptowane przez szkołę bolońską ${ }^{11}$ i otrzymały nazwę

10 Izydor, Etymologiarum libri XX, ks. II, 10, 1: „lex a legendo vocata est, quia scripta est". Gra słów lex a legendo nie do oddania w języku polskim.

11 A.M. Stickler, Historia iuris canonici latini. Institutiones academicae, t. 1: Historia fontium, Turyn 1950, s. 220. 
Quinque compilationes antiquae. Był on według numeracji trzeci, ale chronologicznie drugi. Stało się tak dlatego, że zawierał według chronologii późniejszy materiał prawny od tego zamieszczonego w następnym zbiorze $^{12}$. Wówczas papież Innocenty III (1198-1216) polecił Piotrowi Collivaccino lub Beneventano przygotować zbiór jego dekretałów. Miał on zebrać dekretały tego papieża z lat 1198-1209. Prace nad nim Piotr ukończył w 1209 r. Ostatni dekretał nosi datę 29 czerwca 1209 r. ${ }^{13}$ Prawdopodobnie w tym samym roku, na pewno nie po zakończeniu dwunastego roku jego pontyfikatu, a więc nie po 21 lutego $1210 \mathrm{r}^{14}{ }^{14}$, papież wydał bullę zatytułowaną od pierwszych jej słów Devotioni vestrae i wysłał zbiór wraz z bullą do Uniwersytetu w Bolonii. Bulla nosi datę 28 grudnia $1210 \mathrm{r}^{15} \mathrm{~W}$ ten sposób w historii powszechnego prawa kanonicznego dokonała się pierwsza promulgacja i zaistniał pierwszy autentyczny zbiór powszechnego prawa kanonicznego ${ }^{16}$. Zawarte w Compilatio III dekretały zostały ułożone w porządku systematycznym, według systematyki Bernarda z Pawii, który zastosował ją w Compilatio $I^{17}$. Materiał prawny ułożony w 5 księgach i 122 tytułach zawierał 482 capitula $^{18}$. Wewnątrz ksiąg został zachowany porządek chronologiczny, zgodny z czasem wydawania dekretałów. Tekst bulli Devotioni vestrae został umieszczony na początku Compilatio III.

Incipiunt Decretales Domini Innocentii Papae a Magistro P. Beneventano eiusdem Papae subdiacono et notario fideliter compilatae.

Innocentius Episcopus Servus Servorum Dei Universis Magistris et Scolaribus Bononiae commorantibus Salutem et Aposotlicam Benedictionem.

Devotioni vestrae insinuatuione praesentium innotescat, decretales epistolas a dilecto filio magistro $P$. subdiacono et notario nostro compilatas fideliter, et

12 P. Hemperek, W. Góralski, Komentarz do Kodeksu Prawa Kanonicznego, t. 1, cz. 1, Lub$\operatorname{lin} 1995$, s. 93.

13 A.M. Stickler, Historia iuris canonici..., s. 233.

14 Tamże.

15 Taką datę wskazał A. van Hove, Commentarium Lovaniense in Codicem Iuris Canonici. Prolegomena, t. 1, Mechliniae - Romae 1928, s. 173.

16 Tamże.

17 Bernard z Pawii ułożył dekretały z Compilatio I w pięciu księgach, które przez szkołę bolońską zostały nazwane: I księga iudex (o jurysdykcji kościelnej, sędziach, ustawodawcach), II księga iudicium (o sądach), III księga clerus (o osobach w Kościele, głównie o duchownych), IV księga connubium (o małżeństwie), V księga crimen (o przestępstwach i karach). Materiał prawny w obrębie ksiąg układał w porządku chronologicznym.

18 C. van de Wiel, History of Canon Law, Louvain 1991, s. 105. 
sub competentibus titulis collocatas, in nostris usque ad XII. annum contineri registris, quas ad cautelam vobis sub bulla nostra duximus transmittendas, ut eisdem absque quolibet dubitationis scrupulo uti possitis, cum opus fuerit, tam in iudiciis quam in scholis ${ }^{19}$.

Zaczynają się Dekretały papieża Innocentego, wiernie zebrane przez magistra Piotra Benewentańskiego, tegoż papieża subdiakona i notariusza.

Biskup Innocenty Sługa Sług Bożych wszystkim nauczycielom i uczniom przebywającym w Bolonii pozdrowienie i apostolskie błogosławieństwo.

Niech będzie wszystkim na mocy tego pisma wiadomym, że dekretały zebrane wiernie przez umiłowanego syna i nauczyciela Piotra, subdiakona i naszego notariusza, i pod odpowiednimi tytułami umieszczone, znajdują się w naszym regestrze aż do XII roku [pontyfikatu], które dla przezorności poleciłem, żeby zostały przesłane z dołączeniem naszej bulli, abyście mogli posługiwać się nimi bez jakiejkolwiek najmniejszej wątpliwości, gdy będzie potrzeba, tak w sądach, jak i w szkołach ${ }^{20}$.

Papież Innocenty III poprzez dołączenie do przygotowanego przez Piotra z Benewentu zbioru swojej bulli dokonał po raz pierwszy promulgacji zbioru powszechnego prawa kanonicznego. Papież zapewniał w ten sposób, że dekretały są przez niego samego ustanowionym prawem. Piotr zebrał je wiernie, co zostało podkreślone w bulli słowem „fideliter”. Co oznaczało, że zebrał je wszystkie i w takim brzemieniu, jakie nadał im papież. Piotr nie dokonał w nich żadnych zmian. Bulla miała niezwykle istotne znaczenie w obliczu wcześniejszych zbiorów, redagowanych przez prywatnych autorów, którzy dokonywali w tekstach prawnych zmian, a nawet fałszerstw. Papież, jako najwyższy ustawodawca Kościoła, przejmował poprzez taki sposób promulgacji zbioru prawa inicjatywę gromadzenia prawa i wydawania go pod własnym autorytetem ${ }^{21}$. Papież nie zastrzegł jeszcze wówczas wyłączności dla tego zbioru. Było to zrozumiałe, gdyż Compilatio III obejmowała zakres prawa Kościoła tylko z dwunastu lat jego pontyfikatu. Zapewnienie papieża, że dekretały zostały umieszczone pod odpowiednimi tytułami, stanowiło akceptację dla systematyki zastosowanej przez Bernarda z Pawii w Compilatio I. Papież zapewniał, że dekretały znajdują się w regestrze papieskim. Takie stwierdzenie zawarte w bulli dawało pewność, że są to teksty oryginalne. Zwrot „ad cautelam”

\footnotetext{
19 E.A. Friedberg, Quinque compilationes antiquae, Graz 1956, s. 105.

20 Tłumaczenie własne autora opracowania.

21 A.M. Stickler, Historia iuris canonici..., s. 234.
} 
zastosowany $\mathrm{w}$ bulli jest dowodem na troskę papieża o pewność w korzystaniu ze zbioru. Bulla ma być dowodem na autentyczność zawartego $\mathrm{w}$ zbiorze prawa. Ten promulgacyjny papieski dokument sprawił, że nie można tych dekretałów podejrzewać o nieautentyczność22. Dzięki temu adresaci norm prawa będą mogli korzystać ze zbioru, jak to napisał papież, „,bez jakiejkolwiek najmniejszej wątpliwości”. Również zupełnie nowym elementem jest skierowanie tekstu zbioru do nauczycieli i uczniów szkoły prawa w Bolonii. Papież uznał w ten sposób autorytet nauki prawa. Szkoła nie była jedynym adresatem zbioru. Należało się nim posługiwać, "gdy będzie potrzeba", "tak w sądach, jak i w szkołach". Papież wskazał w ten sposób dwóch adresatów swoich norm. Prawo ma być więc stosowane w sądach, a poddane dyskursowi naukowemu w szkołach. Ta forma promulgacji zbioru stanie się wzorcowa na przyszłość i będzie kontynuowana, z niewielkimi zmianami, aż do naszych czasów.

\section{Compilatio $V$}

Kolejnym promulgowanym zbiorem powszechnego prawa kanonicznego była Compilatio V. Zbiór ten został sporządzony przez nieznanego autora na polecenie papieża Honoriusza III (1216-1227). Znajdują się w nim dekretały wydane przez tegoż papieża $\mathrm{w}$ okresie jego pontyfikatu ${ }^{23}$. Do tego zbioru została dołączona konstytucja cesarza Fryderyka II z 1220 r. zawierająca przywileje nadane Kościołowi. Materiał prawny został ułożony w porządku $5 \mathrm{ksiąg} \mathrm{(iudex,} \mathrm{iudicium,} \mathrm{clerus,} \mathrm{connubia,} \mathrm{crimen).} \mathrm{W} \mathrm{nich} \mathrm{znaj-}$ dują się 94 tytuły, zawierające 223 capitula. Promulgacji zbioru dokonał papież Honoriusz III bullą Novae causarum z 2 maja 1226 r. ${ }^{24}$ Zbiór z dołączoną do niego bullą skierował papież do Tankreda, który był profesorem i rektorem Uniwersytetu Bolońskiego oraz archidiakonem bolońskim. Zbiór został przyjęty przez szkołę prawa w Bolonii i otrzymał nazwę Compilatio $\mathrm{V}$.

22 Tamże.

23 A. van Hove, Commentarium Lovaniense..., s. 174.

24 Tę datę promulgacji ustalił S. Kuttner na podstawie jednego z kodeksów londyńskich, A.M. Stickler, Historia iuris canonici..., s. 236, przyp. 2; S. Kuttner, Repertorium der Kanonistik (1140-1234). Prodromus corporis glossarum, t. 1, Cittá del Vaticano 1937, s. 382, przyp. 2. 
Był to drugi w historii promulgowany przez najwyższego ustawodawcę kościelnego zbiór powszechnego prawa kanonicznego ${ }^{25}$.

Honorius Episcopus, Servus Servorum Dei, Dilecto Filio Magistro Tancredo, Archidiacono Bononiensi Salutem et Apostolicam Benedictionem.

Novae causarum emergentium questiones novis exigunt decisionibus terminari, ut singulis morbis, competentibus remediis deputatis, ius suum cuique salubriter tribuatur. Licet igitur a quibusdam predecessoribus nostris per ea que, suis temporibus sunt decisa, forma futuris negotiis prouide sint relicta, quia tamen prodiga rerum natura secundum uarietates multiplicium casuum parit cottidie nouas causas, nos quasdam epistolas decretales super his, que nostris suborta temporibus, per nos uel fratres nostros decidimus, uel etiam aliis de ipsorum consilio commisimus decidenda, compilari fecimus, et tibi sub bulla nostra duximus destinandas. Quocirca discretioni tuae per apostolica scripta mandamus, quatinus eis solempniter publicatis absque ullo scrupulo dubitationis utaris et ab aliis recipi facias tam in iudiciis quam in scholis ${ }^{26}$.

Biskup Honoriusz, Sługa Sług Bożych, Umiłowanemu Synowi Nauczycielowi Tankredowi, Archidiakonowi Bolońskiemu Pozdrowienie i Apostolskie Błogosławieństwo.

Nowe problemy rodzących się spraw wymagają, aby były rozstrzygane przy pomocy nowych decyzji, aby poszczególnym chorobom, po przeznaczeniu odpowiednich środków, każdemu zbawiennie była oddana sprawiedliwość. Chociaż więc przez niektórych naszych poprzedników poprzez te, które $\mathrm{w}$ swoim czasie zostały rozstrzygnięte, $\mathrm{w}$ formie przyszłych zdarzeń przewidująco zostały pozostawione, ponieważ bogata natura rzeczy stosownie do różnorodności licznych przypadków rodzi codziennie nowe sprawy, my, pewne dekretały odnośnie do tych spraw, które zrodziły się w naszych czasach, przez nas albo przez naszych braci rozstrzygnęliśmy, albo nawet powierzyliśmy innym, aby przez nich samych zostały rozstrzygnięte, sprawiliśmy, aby były zebrane i poleciliśmy, żeby wraz z naszą bullą dla ciebie zostały przeznaczone. Dlatego przez apostolskie pismo powierzamy twojej roztropności, abyś nimi, po ich uroczystym ogłoszeniu, bez jakiejkolwiek najmniejszej wątpliwości posługiwał się i sprawił ${ }^{27}$, aby były przez innych przyjęte, tak w sądach, jak i w szkołach.

25 P. Hemperek, W. Góralski, Komentarz..., s. 95.

26 E.A. Friedberg, Quinque compilationes antiquae..., G. 151.

27 Papież polecił, zalecił, nawet rozkazał, aby był przyjęty "tak w sądach, jak i w szkołach", A.M. Stickler, Historia iuris canonici..., s. 236 zwrócił na to uwagę, używając 
Decyzja o sporządzeniu zbioru była wyłączną inicjatywą papieża Honoriusza III. W tekście bulli znajduje się stwierdzenie „compilari fecimus”, które wskazuje na tę inicjatywę. Użyty w tekście bulli zwrot „ius suum cuique salubriter tribuitur ${ }^{28 \prime}$ to istotny element definicji sprawiedliwości, której autorstwo przypisuje się Ulpianowi. Dodany przysłówek „salubriter" (zbawiennie) wskazuje na szczególny rodzaj sprawiedliwości w prawie kanonicznym, którym jest troska o ziemski wymiar sprawiedliwości, nakierowanej w ostateczności na zbawienie dusz (salus animarum). Papież zaznacza, że jego poprzednicy wydawali również dekretały, w których dokonywali prawnych rozstrzygnięć, a które pozostały na przyszłość, aby regulować różne zdarzenia. Kazuistyczny sposób stanowienia prawa uniemożliwiał rozstrzyganie nowych spraw, których specyfika domagała się nowych regulacji prawnych. Papież mówił o „uarietates multiplicium casuum" (różnorodność licznych przypadków). Stawiał na równi rozstrzygnięcia prawne spraw dokonanych przez niego samego, przez innych biskupów i przez tych, którym polecił rozstrzygać. Zebrane w jeden zbiór dekretały Honoriusz III przeznaczył dla Tankreda ${ }^{29}$ profesora i rektora Uniwersytetu Bolońskiego. Skierował do niego pismo apostolskie, które było świadectwem autentyczności zawartych w zbiorze dekretałów. Z tekstu bulli można wnioskować, że uroczystego ogłoszenia, czyli promulgacji, miał dokonać Tankred na uniwersytecie. Miał się on też posługiwać tym tekstem i to bez „jakiejkolwiek najmniejszej wątpliwości”.

i podkreślając to słowem „praecipit”. Autor ten zwrócił uwagę na to, że, o ile, zbiór Innocentego III Compilatio III miał być ogłoszony (declarat) i papież polecił jego przyjęcie, to papież Honoriusz III nakazał przyjęcie swojego zbioru i posługiwanie się nim „,tak w sądach, jak i w szkołach".

28 Dig. 1, 1, 10 pr. Ulpianus libro secundo regularum „Iustitia est constans et perpetua voluntas ius suum cuique tribuendi".

29 P. Hemperek, W. Góralski, Komentarz..., s. 95; A. van Hove, Commentarium Lovaniense..., s. 174. O ile fakt skierowania zbioru i bulli do Tankreda jest oczywisty, wynika z tekstu bulli, to odnośnie do autorstwa sporządzenia zbioru opinie są rozbieżne. A. van Hove, Commentarium Lovaniense..., s. 174 stwierdził, że "Compilatio V ... iussu huius Pontificis confecta est ab auctore ignoto". P. Hemperek, W. Góralski, Lomentarz..., s. 95 prawdopodobne autorstwo zbioru przypisują Tankredowi „Wykonawcą postanowienia papieża był najprawdopodobniej znany dekretalista boloński Tankred”. Podobnie A.M. Stickler, Historia iuris canonici..., s. 235-236 stwierdził „per Tankredum ... collectionem ... congerendam curavit". Autor ten twierdził, że możliwe jest, iż zbiór wraz z bullą papież Honoriusz III skierował również do Marcina w Padwie „forsan etiam ad Martinum, magistrum Patavinum". 
Tankredowi powierzył troskę o to, aby przez innych zostały przyjęte. Dekretały zawarte w zbiorze miały być przyjęte w sądach i w szkołach. Stanowi to dowód powagi i autorytetu, jakim cieszył się Tankred jako profesor i rektor. Należy zauważyć szczególny związek uniwersytetu i sądów. Ten sam zbiór miał stać się podstawą rozstrzygania spraw w sądach i przedmiotem dyskursu naukowego na uniwersytetach. Przy czym porządek adresatów prawa zawartego w zbiorze nie jest przypadkowy. Najwyższy ustawodawca Kościoła polecił, aby jego prawo stosować w sądach. W praktyce to jest pierwszy adresat stanowionego prawa. Papież dawał sędziom sądów kościelnych autentyczne, dostosowane do wymogu czasów normy prawne, na podstawie których mieli sądzić zaistniałe zdarzenia. Równocześnie normy te miały być poddane dyskursowi naukowemu. Tak - od czasu Dekretu Gracjana - rozwijała się doktryna prawa. Był to rok 1226, a więc istniał już uniwersytet w Padwie ${ }^{30}$. Stąd bardzo prawdopodobne jest przypuszczenie, że bulla wraz z tekstem Compilatio $V$ została przesłana do rektora Marcina, profesorów i studentów uniwersytetu w Padwie. ${ }^{31}$

\section{Dekretaty Grzegorza IX}

Kolejnym zbiorem będącym owocem współpracy Stolicy Apostolskiej i nauki, władzy ustawodawczej i doktryny były Dekretały Grzegorza IX ${ }^{32}$. Papież Grzegorz IX polecił w 1230 r. Raymundowi de Peñafort, aby sporządził nowy zbiór dekretałów. Raymund studiował prawo w Bolonii, a następnie uczył tam prawa. Później został kapelanem i penitencjarzem papieża. Nowy zbiór sporządził w ciągu czterech lat. Materiał prawny ułożył w porządku systematycznym pięciu ksiąg (iudex, iudicium, clerus, connubia, crimen). Zachował więc systematykę Bernarda z Pawii zastosowaną w Compilatio I. W sumie w zbiorze było 185 tytułów i 1971 capitula.

30 Został on założony w 1222 roku. Dokonała tego grupa profesorów i studentów z Uniwersytetu Bolońskiego, którzy domagali się większych swobód i dlatego opuścili swój macierzysty uniwersytet i założyli nowy, właśnie w Padwie. Nauczanie prowadzono w dwóch dyscyplinach, prawie i teologii.

31 A.M. Stickler, Historia iuris canonici..., s. 235-236, „forsan etiam ad Martinum, magistrum Patavinum".

32 Tamże, s. 238. 
W dniu 5 września 1234 roku papież Grzegorz IX wydał w Spoleto bullę Rex pacificus i promulgował zbiór poprzez przesłanie do Uniwersytetu Bolońskiego i prawdopodobnie Paryskiego oraz być może także do innych uniwersytetów ${ }^{33}$.

\section{Gregorius}

Episcopus servus servorum Dei, dilectis filiis doctoribus et scholaribus universis Bononiae commorantibus salutem et apostolicam benedictionem.

Rex pacificus pia miseratione disposuit sibi subditos fore pudicos, pacificos et honestos. Sed effrenata cupiditas, sui prodiga, pacis aemula, mater litium, materia iurgiorum, tot quotidie nova litigia generat, ut, nisi iustitia conatus eius sua virtute reprimeret, et quaestiones ipsius implicitas explicaret, ius humani foederis litigatorum abusus exstingueret, et dato libello repudii concordia extra mundi terminos exsularet. Ideoque lex proditur, ut appetitus noxius sub iuris regula limitetur, per quam genus humanum, ut honeste vivat, alterum non laedat, ius suum unicuique tribuat, informatur. Sane diversas constitutiones et decretales epistolas praedecessorum nostrorum, in diversa dispersas volumina, quarum aliquae propter nimiam similitudinem, et quaedam propter contrarietatem, nonnullae etiam propter sui prolixitatem, confusionem inducere videbantur, aliquae vero vagabantur extra volumina supradicta, quae tanquam incertae frequenter in iudiciis vacillabant, ad communem, et maxime studentium, utilitatem per dilectum filium fratrem Raymundum, capellanum et poenitentiarum nostrum, illas in unum volumen resecatis superfluis providimus redigendas, adiicientes constitutiones nostras et decretales epistolas, per quas nonnulla, quae in prioribus erant dubia, declarantur. Volentes igitur, ut hac tantum compilatione universi utantur in iudiciis et in scholis, districtius prohibemus, ne quis praesumat aliam facere absque auctoritate sedis apostolicae speciali ${ }^{34}$.

\section{Grzegorz}

Biskup sługa sług Bożych, umiłowanym synom doktorom i wszystkim studentom przebywającym w Bolonii pozdrowienie i apostolskie błogosławieństwo.

Król Pokoju w swojej miłosiernej łaskawości postanowił, że jemu poddani będą skromni, spokojni i prawi. Lecz nieokiełznana żądza, trwoniąca swoje, wróg pokoju, matka sporów, przyczyna kłótni, rodzi codziennie tak wiele

33 Tamże, s. 242.

34 Decretalium D. Gregorii Papae IX. Compilatio, Bulla Rex Pacificus, w: E. Friedberg, Corpus Iuris Canonici, t. 2, Graz 1959, kol. 1-4. 
sporów, że gdyby sprawiedliwość nie powstrzymywała jej dążeń swoją siłą i nie wyjaśniała jej zagmatwanych spraw, prawo ludzkiego przymierza nie zniszczyło występków stron procesowych, to, dawszy list rozwodowy, zgoda byłaby wygnana poza granice świata. Dlatego ustanawia się prawo, aby szkodliwe dążenia były ograniczone zasadami prawa, przez które rodzaj ludzki jest pouczany, aby uczciwie żył, drugiemu nie szkodził, oddawał każdemu to, co mu się należy. [„Zaiste różne konstytucje i dekretały, rozproszone w różnych zbiorach, jedne $\mathrm{z}$ racji podobieństwa, inne z powodu sprzeczności, niektóre ze względu na rozwlekłość, wydawały się powodować zamieszanie, jeszcze inne zaś pozostawały poza wymienionymi zbiorami i były często traktowane w sądach jako niepewne, przeto dla powszechnego, a zwłaszcza studiujących pożytku postanowiliśmy je [...] po usunięciu zbędnych zredagować w jednym tomie, dodając nasze konstytucje i dekretały, aby z ich pomocą wyjaśnić kwestie, które we wcześniejszych były wątpliwe. Chcąc zatem, aby tylko tą kompilacją powszechną posługiwano się w sądach i w szkołach, stanowczo zabraniamy, żeby ktokolwiek odważył się sporządzić inną bez specjalnego upoważnienia Stolicy Apostolskiej"] $]^{35}$.

\section{Liber sextus Bonifacego VIII}

Nowe normy prawne miały być dołączane do poszczególnych tytułów Dekretałów Grzegorza IX. Jednak w praktyce zamysł ten nie przyjął się. Tworzono więc nowe zbiory zarówno autentyczne, jak i prywatne, ale nie znajdowały one uznania ani w sądach, ani w szkole. Do próśb kanonistów, aby sporządzić nowy autentyczny zbiór, przychylił się papież

35 W. Góralski, P. Hemperek, Komentarz..., s. 97. „Rzeczywiście, różne przepisy prawa i dekretały naszych poprzedników, rozproszone w różnych księgach, spośród których wydawało się, że niektóre z powodu zbytniego podobieństwa, a pewne z powodu przeciwieństw, niektóre także z powodu rozciągłości wprowadzają zamęt, pewne zaś krążyły poza wyżej wspomnianymi księgami, które często w sądach jakby niepewne budziły wątpliwości, zatroszczyliśmy się, żeby dla wspólnego pożytku, a najszczególniej studiujących, zostały przez umiłowanego syna [i] brata Rajmunda, kapelana i penitencjarza naszego, po odrzuceniu zbędnych, zebrane w jednym tomie, dołączając nasze przepisy prawa i dekretały, przez które, pewne były oficjalnie ogłoszone, które we cześniejszych były wątpliwe. Chcemy więc, aby wszyscy posługiwali się tylko tym zbiorem, tak w sądach, jak i w szkołach, surowo zabraniamy, aby ktokolwiek odważył się sporządzić inny, bez specjalnego pozwolenia Stolicy Apostolskiej". Tłumaczenie autora opracowania. 
Bonifacy VIII (1294-1303). Sam będąc znakomitym kanonistą, który studiował prawo kanoniczne w szkole w Bolonii w latach 1260-1264, polecił przygotować nowy zbiór. Zadanie to powierzył trzem profesorom prawa kanonicznego: Wilhelmowi de Mandagoto ${ }^{36}$, Berengariuszowi Fredolii ${ }^{37}$ i Ryszardowi Petroniuszowi de Senis ${ }^{38}$. Papież pozwolił im na dokonywanie wszelkich zgodnych z prawem i nauką prawa zmian, tak że w efekcie powstał zbiór nowych tekstów, dostosowanych do ówczesnej techniki budowy tekstów prawnych. Pracę wykonali w ciągu dwóch lat (1296-1298). Papież Bonifacy VIII w dniu 3 marca 1298 r. skierował zbiór wraz z bullą Sacrosanctae Romanae Ecclesiae do uniwersytetów w Bolonii, Paryżu, jak i do innych ważniejszych uniwersytetów z poleceniem, aby tym zbiorem posługiwano się tam in iudiciis quam in scholis.

\section{Bonifacius,}

episcopus servus servorum Dei, dilectis filiis doctoribus et scholaribus universis Bononiae ${ }^{39}$ commorantibus salutem et apostolicam benedictionem.

Sacrosanctae Romanae ecclesiae, quam imperscrutabilis divinae providentiae altitudo universis dispositione incommutabili praetulit ecclesiis et totius orbis praecipuum obtinere voluit magistratum, regimini praesidentes, curis sollicitamur continuis, et assidua meditatione urgemur, ut iuxta creditae nobis dispensationis officium subditorum commodis, in quorum prosperitate utique prosperamur, iugi, quantum nobis ex alto concessum fuerit, sollicitudinis studio intendamus. Amplectimur quippe voluntarios pro ipsorum quiete labores, et noctes quandoque transimus insomnes, ut scandala removeamus ab ipsis, et, quas humana natura, novas semper deproperans edere formas, lites quotidie invenire conatur, nunc antiquorum declaratione, nunc

36 Pochodził z Galii, studiował w Bolonii, był kapelanem papieskim, w 1295 r. został arcybiskupem Embrun, w 1311 r. został biskupem w Aquae, która to diecezja była sufraganalną dla Turynu, w 1312 r. został kardynałem, zmarł w 1321 r. A.M. Stickler, Historia iuris canonici..., s. 259; W. Góralski, P. Hemperek, Komentarz..., s. 105.

37 Pochodził z Galii, był kapelanem papieskim, doktorem dekretów, profesorem w Paryżu, od 1294 r. był biskupem w Béziers we Francji, został kardynałem, zmarł w 1323 r. A.M. Stickler, Historia iuris canonici..., s. 259; W. Góralski, P. Hemperek, Komentarz..., s. 105.

38 Studiował w Bolonii, uczył prawa rzymskiego w Neapolu, został wicekanclerzem kurii rzymskiej, w 1298 r. został kardynałem, zmarł w 1314 r. A.M. Stickler, Historia iuris canonici..., s. 259; W. Góralski, P. Hemperek, Komentarz..., s. 105.

39 E. Friedberg, Corpus Iuris Canonici..., t. 2, kol. 933, przyp. 1, gdzie zawarte są wskazania, że w różnych kodeksach wymieniane są także inne uniwersytety:w Tuluzie, Padwie, Orleanie, Salamance. 
vero novorum editione iurium, prout nobis est possibile, reprimamus. Sane, quum post volumen decretalium, a felicis recordationis Gregorio Papa IX. praedecessore nostro tam provide quam utiliter compilatum, nonnullae ab eo et $\mathrm{ab}$ aliis Romanis Pontificibus successive super diversis dicerentur articulis editae decretales, de quarum aliquibus, an decretales exsisterent, earumque auctoribus dubitabatur sollicite in iudiciis et in scholis: nos, ad apicem summi pontificatus superna dispositione vocati, super hoc cum instantia requisiti a multis, ambiguitatem et incertitudinem huiusmodi, dispendium pluribus afferentem, omnino tollere, ac elucidare, quae de decretalibus ipsis teneri, quaeve deberent in posterum refutari, gratia suffragante divina pro utilitate publica desiderabiliter affectantes, per venerabiles fratres nostros Guilelmum archiepiscopum Ebrudunensem, et Berengarium episcopum Biterensem, ac dilectum filium magistrum Richardum de Senis, sanctae Romanae ecclesiae vicecancellarium, iuris utriusque doctorem, decretales huiusmodi diligentius fecimus recenseri, et tandem, pluribus ex ipsis, quum vel temporales, aut sibi ipsis vel aliis iuribus contrariae, seu omnino superfluae viderentur, penitus resecatis, reliquas, quibusdam ex eis abbreviatis, et aliquibus in toto vel in parte mutatis, multisque correctionibus, detractionibus et additionibus, prout expedire vidimus, factis in ipsis, in unum librum cum nonnullis nostris constitutionibus, in quibus ad correctionem morum subditorumque quietem multa statuuntur salubria, fructus uberes Deo propitio in domo Domini allatura, et plurima in iudiciis et extra frequentata dubia deciduntur, redigi mandavimus, et sub debitis titulis collocari. Quem librum, quinque libris aliis dicti voluminis decretalium adnectendum, sextum censuimus nuncupari, ut idem volumen senarium, qui numerus est perfectus, librorum illo adiuncto numerum comprehendens, perfectam in rebus agendis formam tribuat et in moribus disciplinam. Nec sine causa morem praedecessorum nostrorum, qui, quum constitutiones aliquas promulgabant noviter, eas mandabant sub antiquarum serie situari, omisimus in hac parte servare. Haec enim fecimus, ne infinitos libros destrui, et alios non sine maximis dispendiis, laboribus et expensis de novo fieri oporteret. Universitati vestrae igitur per apostolica scripta mandamus, quatenus librum huiusmodi cum multa maturitate digestum, quem sub bulla nostra vobis transmittimus, prompto suscipientes affectu, eo utamini de cetero in iudiciis et in scholis, nullas alias praeter illas, quae inseruntur aut specialiter reservantur in eo, decretales aut constitutiones, a quibuscunque nostris praedecessoribus Romanis Pontificibus post editionem dicti voluminis promulagatas, recepturi ulterius aut pro decretalibus habituri" 40 .

40 Tamże, kol. 933-936. 
Bonifacy,

biskup sługa sług Bożych, wszystkim umiłowanym synom doktorom i studentom przebywającym w Bolonii

pozdrowienie i apostolskie błogosławieństwo.

Sprawując najwyższy urząd Najświętszego Kościoła Rzymskiego, który niezbadaną głębią Bożej Opatrzności niezmiennym postanowieniem postawiła na czele wszystkich Kościołów i chciała, aby miał szczególną władzę w całym świecie, poruszani jesteśmy nieustannymi troskami i przynaglani jesteśmy codziennym postanowieniem, że według powinności powierzonego nam urzędu, z najgłębszą troską będziemy starali się, żeby było udzielone dla korzyści podwładnych, w pomyślności których jest oczywiście nasze szczęście, ile tylko nam z góry będzie przyznane. Podejmujemy oczywiście chętnie dla spokoju podwładnych prace i niekiedy spędzamy bezsennie noce, aby odsunąć od nich zgorszenia i nowe spory, które natura ludzka, starając się wydać nowe ich postaci, usiłuje codziennie wynaleźć, tak, jak jest to dla nas możliwe tłumimy, czy to objaśnianiem starych, czy to wydawaniem nowych praw. Rzeczywiście, po przygotowaniu zbioru dekretałów sporządzonego, tak przewidująco, jak pożytecznie, przez świętej pamięci Grzegorza IX naszego poprzednika, niektóre dekretały wydane po kolei przez niego i innych papieży odnośnie do różnych wypadków, co do niektórych spośród nich wątpiono z niepokojem w sądach i w szkołach co do ich autorów i czy istniały jako dekretały: my, powołani zrządzeniem Niebios do godności papieskiej, odnośnie do tego, usilnie proszeni przez wielu, wątpliwość i niepewność tego rodzaju, przynoszącą licznym szkodę, zupełnie usunąć i wyjaśnić, które spośród tych dekretałów obowiązują, a które z tych dekretałów na przyszłości powinny być odrzucone, z pomocą łaski Bożej, gorąco pragnąc, dla pożytku publicznego przez czcigodnych braci naszych Wilhelma arcybiskupa Embrun i Berengariusza biskupa Béziers, a także umiłowanego syna magistra Ryszarda de Senis wicekanclerza Świętego Kościoła Rzymskiego, doktora obojga praw, sprawiliśmy, że tego rodzaju dekretały zostały dokładnie przejrzane, i ostatecznie wiele z nich zostało zupełnie usuniętych, ponieważ były albo czasowe, albo były sprzeczne same ze sobą lub z innymi przepisami, czy też wydawały się zupełnie zbyteczne, pozostałe, po skróceniu niektórych i po dokonaniu zmian w części lub w całości, po dokonaniu w nich licznych poprawek, cięć i dodatków, tak jak widzieliśmy, że było to potrzebne, wraz z niektórymi naszymi konstytucjami, w których zostało zawartych wiele zbawiennych postanowień dla poprawy obyczajów i spokoju podwładnych, z nadzieją, że przyniosą za łaską Boga w domu Pańskim wiele zbawiennych owoców i położą kres wielu często nasuwającym się wątpliwościom w sądach i poza nimi, poleciliśmy, żeby zostały w jednej księdze ułożone i w odpowiednich tytułach umieszczone. Postanowiliśmy, żeby księga ta, która miała być dołączona do 
innych pięciu ksiąg wspomnianego woluminu dekretałów, była nazywana szóstą, aby ten wolumen zawierający, po dołączeniu go, sześć ksiąg, która to liczba jest doskonała, dostarczał doskonałych przepisów dla prowadzenia procesów sądowych, a w obyczajach zapewniał dyscyplinę. Nie bez powodu pominęliśmy w tej części zachowanie zwyczaju naszych poprzedników, którzy, gdy promulgowali na nowo jakieś konstytucje, polecali, aby były umieszczane w rzędzie wcześniejszych. Uczyniliśmy bowiem tak, aby nie została usunięta nieskończona liczba ksiąg, a innych nie trzeba było od nowa tworzyć nie bez największych strat, wielkich wysiłków i kosztów. Uniwersytetowi waszemu więc przez apostolskie pismo polecamy, abyście tego rodzaju księgą, z tak wielką rozwagą i odpowiedzialnością sporządzoną, którą wraz z bullą naszą wam przesyłamy, z ochczą życzliwością przyjmując, na przyszłość posługiwali się nią w sądach i w szkołach, żadnych innych poza tymi, które w tej księdze znajdują się albo wyraźnie są zastrzeżone, dekretałów albo konstytucji, przez jakichkolwiek naszych poprzedników, papieży, promulgowanych, po wydaniu wymienionego woluminu, więcej nie przyjmowali ani nie uznawali za dekretały.

\section{Klementyny}

Po promulgacji Liber sextus Bonifacego VIII, zgodnie z zasadą ius sequitur vitam, były stanowione przez papieży nowe normy prawne regulujące pojawiające się nowe sytuacje związane rozwojem nowych instytucji kanonicznych, obroną praw Kościoła, jak i naprawą obyczajów. Nowe dekretały dołączano do Liber sextus, a prywatne zbiory dołączano jako dodatki do tego zbioru. Tak, jak każdy papież, nowe dekretały wydawał także Klemens V (1305-1314). Ponadto zwołał on sobór w Vienne, odbywający się w latach 1311-1312, na którym uchwalono wiele konstytucji. Papież postanowił, aby z jego dekretałów i konstytucji soboru w Vienne sporządzić nowy zbiór. Nie zostały włączone do tego zbioru dekretały poprzedników Klemensa V z lat 1298-1304, co było spowodowane konfliktem pomiędzy papieżem Bonifacym VIII i królem Francji Filipem IV Pięknym. Podczas ostatniej sesji soboru w Vienne, która miała miejsce 6 maja 1312 r., papież Klemens V uznał odczytane konstytucje soborowe i uznał je za uchwalone, mimo że nie zostały jeszcze ostatecznie zredagowane. Co istotne, moc wiążącą jako prawo miały uzyskać po przesłaniu do uniwersytetów, co papież uznał za właściwą drogę promulgacji zbioru. Miano w nim 
uwzględnić także niektóre dekretały papieża Klemensa V. Biskup Rzymu zwołał w zamku Monteux w dniu 21 marca 1314 r. konsystorz, na którym ogłosił tak przygotowany zbiór jako Liber septimus i miał on stanowić dodatek do Liber sextus Bonifacego VIII. Jako obowiązujące prawo miał być traktowany od momentu przesłania go do uniwersytetów w Orleanie, gdzie papież studiował, oraz w Paryżu. Poprzez taką decyzję Klemens V kontynuował sposób promulgacji swoich poprzedników. Istotny był też związek urzędującego papieża z miejscem wykształcenia. W tym względzie nawiązywał również do swoich poprzedników. Papież przygotował bullę Cum nuper i wraz z nią miał przesłać zbiór do tych uniwersytetów. Jednak w dniu 20 kwietnia 1314 r. zmarł i nie została dokonana promulgacja zbioru. Następca Klemensa V, papież Jan XXII (1316-1334) polecił dokonać pewnych poprawek tekstu i tak przygotowany zbiór promulgował bullą Quoniam nulla 25 października 1317 r. poprzez przesłanie go do uniwersytetów w Bolonii i w Paryżu oraz prawdopodobnie do innych uniwersytetów ${ }^{41}$. Tekst bulli Quoniam nulla:

\section{Ioannes}

Episcopus servus servorum Dei, dilectis filiis doctoribus et scholaribus universis Bononiae ${ }^{42}$ commorantibus, salutem et apostolicam benedictionem. Quoniam nulla iuris sanctio, quantumcunque perpenso digesta consilio, ad humanae naturae varietatem et machinationes eius inopinales sufficit, nec ad decisionem lucidam suae nodosae ambiguitatis attingit, eo praesertim, quod vix aliquid adeo certum clarumque statutitur, quin ex causis emergentibus, quibus iura iam posita mederi non possint, in dubium revocetur; quia etiam ab adolescentia viri proclivis ad malum sensualitas humana declinat, per quod morum subversio in clero et populo frequenter obrepit: necessaria est superioris auctoritas, ut tam per determinationis opportunae suffragium tollat ambigua, lites auferat, altercationes dirimat et obscura succidat, quam per cultoris providi sarculum exstirpet vitia, virtutes inserat, corrigat excessus moresque reformet. Haec sane felicis recordationis Clemens Papa V. praedecessor noster prudenter attendens, et provide cupiens deformatorum reformationi prospicere, solvere difficilia, ac sanctiones quaestionibus et negotiis imminentibus consonas promulgare, dudum nedum in concilio Viennensi, quin etiam ante et post ipsum concilium constitutiones plurimas edidit, in quibus multa utilia

${ }^{41}$ W. Góralski, P. Hemperek, Komentarz..., s. 108-109; A.M. Stickler, Historia iuris canonici..., s. 264-267.

42 Są kodeksy, w których wymieniane są inne uniwersytety, w Paryżu, Awinionie, E. Friedberg, Corpus Iuris Canonici..., t. 2, kol. 1129-1130. 
statuit atque salubria, et nonulla dubia in iudiciis et extra frequentata decidit. Et licet eas, collectas in unum volumen et sub congruis titulis collocatas, mittere decrevisset et dare in commune subiectis: assidua tamen occupatio circa magna, ac sortis humanae conditio, quae ipsum de medio sustulit, in causa fuerunt, quare suum in hac parte propositum non implevit. Nos etiam, qui, sicut eidem, licet immeriti, in apostolatus officio Domino permittente successimus, sic et in affectus plenitudine in his, quae compendium universi concernunt, successisse debemus, tot grandibus agendis et arduis fuimus a nostrae promotionis exordio circumsepti, quod tam ex hoc quam ex causis rationalibus aliis, quas sub silentio providimus committendas, praedictas vobis communicare constitutiones fuimus hactenus impediti. Nunc igitur opportunitate captata illas vobis sub bulla nostra transmittimus, universitati vestrae per apostolica scripta mandantes, quatenus eas prompto affectu suscipiatis et studio alacri, eis, sic vobis manifestatis et cognitis, usuri de cetero in iudiciis et in scholis. Data Avinione VIII. Kal. Novembris Pontificatus nostri anno secundo ${ }^{43}$.

Jan

biskup sługa sług Bożych, wszystkim umiłowanym synom doktorom i studentom przebywającym w Bolonii, pozdrowienie i apostolskie błogosławieństwo.

Ponieważ żadna sankcja prawa, po jakkolwiek wielkim i dokładnym rozważeniu byłaby zarządzona, nie wystarczy na zmienność natury ludzkiej i jej niespodziewane podstępy, ani nie uzyskuje jasnego rozstrzygnięcia swojej skomplikowanej dwuznaczności, szczególnie dlatego, że ledwie coś właśnie pewnego i jasnego jest ustanawiane, ze względu na pojawiające się sprawy, którym prawa już ustanowione nie mogą zaradzić, jest podawane w wątpliwość; ponieważ także od młodości męża skłonnego zmysłowość ludzka skłania do złego, przez co często i w duchowieństwie, i w ludzie wkrada się zniszczenie obyczajów: konieczna jest władza przełożonego, aby tak przez głos stosownego postanowienia usuwał niepewności, oddalał spory, konczył sprzeczki, niszczył niejasności, jak przez motykę troskliwego ogrodnika, wykorzeniał wady, zasiewał cnoty, karał występki i poprawiał obyczaje. Do tego właśnie świętej pamięci papież Klemens V, poprzednik nasz, roztropnie dążąc i pragnąc przewidująco zadbać o poprawę znieważających, rozwiązać trudności, a także ogłosić publicznie sankcje właściwe zagrażającym sporom i zdarzeniom, dawniej, a jeszcze bardziej na soborze w Vienne, a także przed i po soborze wydał wiele konstytucji, w których zawarł wiele pożytecznych i przydatnych postanowień i usunął niektóre wątpliwości często pojawiające się w sądach i poza sądami. I chociaż je zebrane w jednym tomie i umieszczone

43 Tamże, kol. 1129-1132. 
w odpowiednich tytułach postanowił posłać i dać dla wspólnej korzyści podwładnym: jednak nieustanne zajmowanie się wielkimi sprawami, a także położenie ludzkiego losu, które go spośród nas zabrało, stanowiły przyczynę, dlaczego swojego zamiaru w tym zakresie nie wypełnił. Także my, którzy tak jak po nim samym, chociaż bez zasług, urząd apostolski, za przyzwoleniem Pańskim, objęliśmy, tak też powinniśmy objąć z całym zaangażowaniem to, co dotyczy zwięzłego ujęcia całości, od początku naszej posługi byliśmy opasani tak wielkimi sprawami i trudnościami, że tak z tego powodu, jak innych rozumnych przyczyn, które zatroszczyliśmy się, żeby w tajemnicy zostały dołączone, dotąd byliśmy przeszkodzeni, żeby dać wam wspomniane konstytucje. Teraz więc, korzystając ze sposobności, przesyłamy je wam z naszą bullą, zlecając waszemu uniwersytetowi przez pismo apostolskie, abyście je z ochoczą przychylnością przyjęli i tak wam okazanymi i przez was poznanymi, chętnie i z gorliwością posługiwali się nimi na przyszłość w sądach i w szkołach. Dane w Awinione 25 października, w drugim roku Naszego Pontyfikatu ${ }^{44}$.

\section{Zbiór Grzegorza XIV}

Benedykt XIV (1740-1758), wykształcony w prawie kanonicznym w Bolonii, polecił, aby zebrać wydane przez niego w latach 1740-1746 dokumenty prawne. Tak zebrane stanowiły one jeden tom, który został przez niego promulgowany konstytucją Jam fere sextus ${ }^{45}$ poprzez przesłanie do Bolonii. Ten tom okazał się jedynym i zawierał 146 konstytucji tego papieża wydanych od 1740 r. do 4 stycznia 1746 r. Zbiór wraz z konstytucją skierował „ad magistros et scholares Bononieses” ${ }^{46}$. W konstytucji zawarte było, przyjęte we wcześniejszych bullach papieskich, polecenie posługiwania się nim "tam i iudiciis quam in scholis”. Ten jeden tom stanowi pierwszy z czterech tomów Bullarium Benedicti XIV. Został on włączony do Magnum Bullarium Romanum, które zostało wydane przez Hieronima Mainardiego ${ }^{47}$. Dokumenty zostały ułożone w tomie chronologicznie

44 Czyli 25 października $1317 \mathrm{r}$.

45 Konstytucja ta nie zawiera wskazania dnia i roku. Data wydania ostatniej znajdującej się w zbiorze konstytucji 4 stycznia 1746 r. pozwala na przypuszczenie, że konstytucję promulgującą zbiór napisał po tym dniu i przesłał do uniwersytetu w Bolonii.

46 A.M. Stickler, Historia iuris canonici..., s. 308.

47 H. Mainardi wydał w Rzymie w latach 1734-1744 siedem tomów Bullarium Romanum, w których zawarte były dokumenty papieży do Benedykta XIV włącznie. W. Góralski, P. Hemperek, Komentarz..., s. 120. 
w porządku układu ksiąg i tytułów przyjętym w Corpus Iuris Canonici. Po tej promulgacji aż do promulgacji Codex Iuris Canonici nie miały miejsca promulgacje autentycznych zbiorów władzą najwyższego ustawodawcy kościelnego.

\section{Codex Iuris Canonici 1917}

Zapoczątkowana na Soborze Watykańskim I dyskusja i próby kodyfikacji prawa kanonicznego znalazły swoją kontynuację w decyzji papieża Piusa X. W dniu 19 marca 1904 r. wydał on motu proprio Arduum sane munus, powołując w dokumencie tym komisję, która pod jego przewodnictwem miała podjąć się przygotowania kodeksu prawa kanonicznego. Prace te trwały do 1917 r. W ich trakcie 20 sierpnia 1914 r. zmarł papież Pius X. Wybrany na papieża Benedykt XV (1914-1922) kontynuował prace na kodeksem. W dniu 27 maja 1917 r. wydał on konstytucję apostolską Providentissima Mater Ecclesia, którą promulgował Codex Iuris Canonici. Był to pierwszy w historii Kościoła i prawa kanonicznego kodeks. W pięciu księgach, jednak nie według systemu Bernarda z Pawii: iudex, iudicium, clerus, connubia, crimen, ale raczej według systematyki Instytucji Justyniania: personae, res, actiones, rozmieszczono w księgach, częściach, działach, tytułach, rozdziałach, artykułach materiał prawny. W kodeksie zawarto stare prawo, ale sformułowane $\mathrm{w}$ nowej formie, w postaci krótkich, jasnych i zwięzłych norm ${ }^{48}$. Konstytucja apostolska nosi datę 27 maja 1917 r., którą przyjmuje się za dzień promulgacji, jednak sama uroczystość promulgacji, publicznego ogłoszenia Codex Iuris Canonici miała miejsce w dniu 28 czerwca 1917 r., gdy papież Bendykt XV wobec zgromadzonych kardynałów, konsultorów i współpracowników przygotowujących kodeks, wobec prałatów i pracowników Kurii Rzymskiej uroczyście go promulgował. Jako termin rozpoczęcia obowiązywania ${ }^{49}$ Kodeksu wyznaczono 19 maja 1918 r. Konstytucja była skierowana do episkopatu katolickiego, do wszystkich doktorów i studentów uniwersytetów i seminariów.

48 W. Góralski, P. Hemperek, Komentarz..., s. 129.

49 C. Fantappiè, Storia del diritto canonico e delle istituzioni della Chiesa, Bolonia 2011, s. 268. 


\section{Kodeks Prawa Kanonicznego 1983}

Kluczowym słowem pontyfikatu papieża Jana XXIII (1958-1963) było aggiornamento, które oznaczało przystosowanie Kościoła do wymogów życia w ówczesnym świecie. Rewizja Codex Iuris Canonici 1917 miała zmierzać w kierunku dostosowania kodeksu do ówczesnych potrzeb i miała być powiązana z dziełem soboru, który papież zamierzał zwołać. Sobór rozpoczął się 11 października 1962 r. W dniu 28 marca 1963 r. została ustanowiona Papieska Komisja dla Rewizji Kodeksu Prawa Kanonicznego. W dniu 3 czerwca 1963 r. zmarł papież Jan XXIII. Sobór został zawieszony. Dnia 21 czerwca 1963 r. papieżem został wybrany Paweł VI. Następnego dnia po wyborze polecił kontynuować sobór i pozostał przy decyzji Jana XXIII o dokonaniu rewizji kodeksu. Kardynałowie z Komisji Kodyfikacyjnej podczas pierwszej sesji plenarnej w dniu 12 listopada $1963 \mathrm{r}$. postanowili, że formalne prace nad przygotowaniem kodeksu zostaną odłożone do czasu zakończenia Soboru Watykańskiego II (dnia 8 grudnia 1965 r.). Po tym czasie Komisja Kodyfikacyjna przystąpiła do prac nad przygotowaniem Kodeksu. Prace trwały do 1983 r., kiedy papież Jan Paweł II w dniu 25 stycznia 1983 r. podpisał tekst Kodeksu i konstytucją apostolską Sacrae disciplinae leges promulgował Kodeks Prawa Kanonicznego ${ }^{50}$. Vacatio legis miała trwać do 27 listopada 1983 r. Kodeks został promulgowany powagą najwyższej władzy papieskiej, a konstytucja została zaadresowana do kardynałów, arcybiskupów, biskupów, prezbiterów, diakonów i całego ludu Bożego.

\section{Kodeks Kanonów Kościołów Wschodnich 1990}

Podobnie jak w wypadku Kodeksu dla Kościoła łacińskiego, tak również podczas trwania Soboru Watykańskiego I postulowano ujednolicenie prawa kanonicznego, mając na względzie katolickie obrządki wschodnie. Dzieła tego ujednolicenia podjął się papież Pius XI w 1927 r. W 1929 r. ustanowił Radę Prezydialną, a następnie Komisję Kardynałów do Prac Przygotowawczych Kodyfikacji Wschodniej. Pius XI w 1935 r. powołał Papieską Komisję do Redakcji Kodeksu Prawa Kanonicznego. Gdy przedstawiono 
Piusowi XII tekst kodeksu, papież promulgował z tego tekstu tylko niektóre działy prawa. Podczas trwania obrad Soboru Watykańskiego II postanowiono przygotować kodeks dla Kościołów wschodnich, odpowiadający wierności tradycji wschodniej ${ }^{51}$, jak i duchowi oraz wskazaniom Soboru Watykańskiego II. Papież Paweł VI ustanowił 10 czerwca 1972 r. Papieską Komisję do Rewizji Kodeksu Prawa Kanonicznego Wschodniego. Po wielu latach prac 28 stycznia 1989 r. przedstawiono projekt kodeksu Janowi Pawłowi II z prośbą o promulgację. Dokonał jej Konstytucją apostolską Sacri canones dnia 18 października 1990 r. Kodeks miał obowiązywać od 1 października 1991 r. Uroczysta prezentacja Kodeksu miała miejsce w dniu 25 października 1990 r. podczas 28 kongregacji ósmego Synodu Biskupów w obecności papieża Jana Pawła II ${ }^{52}$.

\section{Zakończenie}

Do początków XIII w. zbiory prawa kanonicznego były gromadzone przez osoby prywatne. Normy prawa powszechnego czy partykularnego w nich zebrane miały wartość prawną taką, jaką nadali im ustawodawcy. W 1210 r. papież Innocenty III dokonał pierwszej w dziejach Kościoła promulgacji zbioru prawa kanonicznego, przesyłając go wraz z bullą do uniwersytetu w Bolonii. W mieście bowiem on sam studiował prawo kanoniczne i tam nastąpił rozkwit szkoły nauk prawnych, prawa i prawa kanonicznego. Z tej szkoły rozwinął się Uniwersytet Boloński, pierwszy $\mathrm{w}$ Europie i w świecie uniwersytet. Stało się to dla przyszłych papieży właściwą drogą promulgacji zbiorów prawa kanonicznego. W 1226 r. zbiór własnych dekretałów z dołączoną do niego konstytucją cesarza Fryderyka II promulgował papież Honoriusz III, przesyłając go wraz z bullą do uniwersytetu w Bolonii. Ten już wówczas wypracowany sposób promulgacji kontynuowali następni papieże, którzy sporządzony zbiór prawa kanonicznego przesyłali wraz z bullami do uniwersytetów z poleceniem, aby tym zbiorem posługiwano się tam in iudiciis quam in scholis, tak w sądach, jak w szkołach. Tak uczynili: w 1234 r. papież Grzegorz IX, Bonifacy VIII w 1298 r. i Jan XXII w 1317 r. Po promulgacji tego ostatniego zbioru,

\footnotetext{
51 Tamże, s. 303-306.

52 W. Góralski, P. Hemperek, Komentarz..., s. 169-171.
} 
który zwykło nazywać się Klementyny, w następnych wiekach, mimo różnych prób, papieże nie sporządzali zbiorów prawa kanonicznego i nie promulgowali ich. Tylko papież Benedykt XIV w 1744 r. przesłał zbiór swoich konstytucji wraz z bullą promulgacyjną do uniwersytetu w Bolonii. Promulgacja mocą władzy najwyższego ustawodawcy w Kościele dokonała się w 1917 r., kiedy papież Benedykt XV promulgował konstytucją apostolską Codex Iuris Canonici. Również Jan Paweł II promulgował konstytucją apostolską Kodeks Prawa Kanonicznego w 1983 r. Konstytucją apostolską promulgował on także Kodeks Kanonów Kościołów Wschodnich w 1990 r. W ten sposób dokonała się, jak dotychczas, ostatnia promulgacja zbioru prawa kanonicznego dokonana władzą najwyższego ustawodawcy Kościoła katolickiego. Sześciu promulgacji dokonali papieże poprzez bulle, trzy poprzez konstytucje apostolskie. Promulgacja zbioru powszechnego prawa kanonicznego mocą władzy najwyższego ustawodawcy kościelnego stanowi realizację zasady prawa lex non promulgata non obligat. Do przebiegu procesu wprowadzenia prawa w życie należy obowiązek ustawodawcy publicznego ogłoszenia zbioru prawa, aby adresaci mogli zapoznać się z normami prawa w zbiorze zawartymi i by mogły one stać się obowiązującym prawem.

\section{Bibliografia}

Burczak K., Dębiński A., Jońca M., Łacińskie sentencje i powiedzenia prawnicze, C.H. Beck, wyd. 3, Warszawa 2018.

Fantappiè C., Storia del diritto canonico e delle istituzioni della Chiesa, Bolonia 2011.

Friedberg E., Quinque compilationes antiquae, Graz 1956.

Friedberg E., Corpus Iuris Canonici, t. 2, Graz 1959.

Hemperek P., Góralski W., Komentarz do Kodeksu Prawa Kanonicznego, t. 1, cz. 1, Lublin 1995.

Hove A. van, Commentarium Lovaniense in Codicem Iuris Canonici. Prolegomena, t. 1, Mechliniae-Romae 1928.

Kuttner S., Repertorium der Kanonistik (1140-1234). Prodromus corporis glossarum, t. 1., Cittá del Vaticano 1937.

Liebs D., Lateinische Rechtsregeln und Rechtssprichwörter, C.H. Beck, wyd. 6, München 1998.

Stownik łacińsko-polski, t. 4, red. M. Plezia, Warszawa 1998.

Stownik łacińsko-polski dla prawników i historyków, red. J. Sondel, Kraków 1997. 
Stickler A.M., Historia iuris canonici latini. Institutiones academicae, t. 1: Historia fontium, Turyn 1950.

Tomasz z Akwinu, Suma Teologiczna, t. 13: Prawo (1-2.90-105), przetłumaczył, w objaśnienia i skorowidze zaopatrzył o. Pius Bełch O. P., Londyn [b.r.w.].

Wiel C. Van de, History of Canon Law, Louvain 1991.

\section{Streszczenie}

Do początków XIII w. zbiory prawa kanonicznego były gromadzone przez osoby prywatne. W 1210 r. papież Innocenty III dokonał pierwszej w dziejach Kościoła promulgacji zbioru prawa kanonicznego, przesyłając go wraz z bullą do uniwersytetu w Bolonii. W 1226 r. zbiór własnych dekretałów z dołączoną do niego konstytucją cesarza Fryderyka II promulgował papież Honoriusz III, przesyłając go wraz z bullą do uniwersytetu w Bolonii. Tak też uczynili: w 1234 r. papież Grzegorz IX, Bonifacy VIII w 1298 r. i Jan XXII w 1317 r. Papież Benedykt XIV w 1744 r. przesłał zbiór swoich konstytucji wraz z bullą promulgacyjną do uniwersytetu w Bolonii. W 1917 r. papież Benedykt XV promulgował Konstytucją apostolską Codex Iuris Canonici. Również Jan Paweł II promulgował konstytucją apostolską Kodeks Prawa Kanonicznego w 1983 r. Papież ten promulgował konstytucją apostolską Kodeks Kanonów Kościołów Wschodnich w 1990 r. Do przebiegu procesu wprowadzenia prawa w życie należy obowiązek ustawodawcy publicznego ogłoszenia zbioru prawa, aby adresaci mogli zapoznać się z normami prawa w zbiorze zawartymi i by mogły one stać się obowiązującym prawem.

Słowa kluczowe: promulgacja, zbiór prawa, papież

\section{THE POPE AND THE PROMULGATION OF UNIVERSAL CANON LAW COLLECTIONS}

\section{Sum mary}

Until the early 13th century, collections of canon law were issued by private individuals. In 1210, Pope Innocent III promulgated a collection of canon law for the first time in the history of the Church, sending it with a bull to the University of Bologna. In 1226, Pope Honorius III promulgated a collection of his own decretals together with the constitution of Emperor Frederick II by sending them with a bull to the University of Bologna. Similar steps were taken by Pope Gregory IX in 1234, Pope Boniface VIII in 1298, and Pope John XXII in 1317. Pope 
Benedict XIV sent a collection of his constitutions with a promulgation bull to the University of Bologna in 1744. In 1917 Pope Benedict XV promulgated Codex Iuris Canonici with an apostolic constitution. Pope John Paul II also promulgated both the Code of Canon Law with an apostolic constitution in 1983 and the Code of Canons of the Eastern Churches with an apostolic constitution in 1990. It is the legislator's obligation within the the process of implementing new laws to publicly announce the collection of law, so that its addressees can become acquainted with the norms of law included in it, and so that these norms can become the applicable law.

Key words: promulgation, collection, pope

\section{ПАПА И ПРОМУЛЬГАЦИЯ СБОРНИКОВ УНИВЕРСАЛЬНОГО КАНОНИЧЕСКОГО ПРАВА}

Резюме

До начала XIII века сборники канонического права собирались частными лицами. В 1210 году Папа Иннокентий III впервые в истории Церкви обнародовал свод канонических законов, отправив его вместе с буллой в Болонский университет. В 1226 году папа Гонорий III обнародовал собрание его собственных декреталов с приложенной к нему конституцией императора Фридриха II, отправив его вместе с буллой в Болонский университет. То же самое сделали папа Григорий IX в 1234 году, Бонифаций VIII в 1298 году и Иоанн XXII в 1317 году. Папа Бенедикт XIV в 1744 году послал сборник своих конституций вместе с буллой обнародования в Болонский университет. В 1917 году Папа Бенедикт XV обнародовал Апостольской конституцией Codex Iuris Canonici. Папа Иоанн Павел II также провозгласил в 1983 году апостольской конституцией Кодекс канонического права. Тот же папа в 1990 году обнародовал апостольской конституцией Кодекс канонов Восточных церквей. Процесс вступления в силу закона включает в себя обязательство законодателя публично объявить свод законов, чтобы адресаты могли ознакомиться с содержащимися в нем нормами и чтобы они стали действующим законом.

Ключевые слова: промульгация, сборник законов, папа 
